\title{
Rebetikamusiikin kitaratyylit ja musiikillinen fuusio
}

"The tradition of Greek culture is one big stomach. He have inside Spain, East, all the Mediterranean sea, from other planet maybe, it's one big stomach..." Hristos Spourdalakis

Tämä artikkeli käsittelee harmonista ajattelua kreikkalaisessa kaupunkimusiikissa eli rebetikassa sekä siinä käytettyjä kitaransoittotyylejä, soittotekniikoita ja niissä tapahtuneita muutoksia 1920-luvulta 1960-luvulle. Aluksi esittelen rebetikakitaran, jonka sointiominaisuudet on suunniteltu erityisesti rebetikaa varten. Toiseksi pohdin rebetikamusiikin säestysharmonioiden alkuperää ja esittelen 1930-luvun kitaransoittotyylejä ja rebetikalle ominaisia soittotekniikoita. Lopuksi vertailen erään sävellyksen 1930-luvun levytyksen ja 1960-luvun uudelleenlevytyksen kitaransoittotyylissä ja harmonisessa ajattelussa tapahtuneita muutoksia.

Kuten Peter Manuel $(1989,70)$ esittää, länsimaiset musiikintutkijat eivät ole olleet kiinnostuneita suurten musiikkikulttuurien fuusioista. Musiikintutkijoita ei myöskään ole kiinnostanut harmoniset ajattelutavat näissä fuusioissa. Rebetikalaulujen soinnuttamisesta - jonka esikuvat löytyvät länsimaisesta musiikista - ei juurikaan löydy tutkimuskirjallisuutta. Tutkijat ovat keskittyneet lähinnä laulu- ja soitinmelodioiden analyysiin tai laulujen sanoituksiin.

Rebetika sai alkunsa Kreikan populaarimusiikkityylinä 1920- ja 1930-luvuilla. Se syntyi kahden musiikkityylin kohtaamisesta. Mannerkreikkalainen teké-tyyli, josta rebetika varsinaisesti kehittyi, oli ennen 1930-lukua vankiloissa ja hasiskapakoissa, tekéissä, soitettua musiikkia. Teké-tyylin musiikki oli lähinnä kreikkalaisella pitkäkaulaluutulla, buzukilla ja sen pienoismuodolla, baglamalla säestettyjä miesten esittämiä lauluja, johon kuului improvisoituja vapaametrisiä sooloja, taksimeita. Säestyssoittimena oli usein kitara. (Smith 1991, 322-324; Holst 1989, 44)

Vuosien 1922 ja 1923 aikana Ateenaan ja sen satamakaupunkiin Pireukseen muutti satojatuhansia anatoliankreikkalaisia pakolaisia ${ }^{1}$. He toivat mukanaan oman musiikkinsa, smyrneikon eli café-aman -tyylin. Tämä kaupunkimusiikkityyli

1) Anatolian sodan seurauksena tapahtuneen ns. Smyrna- tai Vähän-Aasian-katastrofin (1922-1923) seurauksena lähes koko Anatolian kreikkalaisvähemmistö siirrettiin Manner-Kreikkaan. 
sai nimensä café-aman -kahviloiden mukaan, joita oli kreikkalaisten asuttamissa satamakaupungeissa, kuten Smyrnassa (Izmir) ja Konstantinopolissa (Istanbul).

Café-aman -tyylin musiikkia lauloivat sekä miehet että naiset. Melodiasoittimina olivat viulut, sellot, ud-luutut, kanun ja sandourit. Säestyksessä käytetiin zilejä eli sormilautasia, defiä eli kalvotamburiinia ja myös keraamista tai metallista turkkilaista rumpua, toumbelekia. Myöhemmin café-aman -tyylissä käytettiin säestyssoittimena myös kitaraa ja pianoa (Holst 1989, 71).

Teké- ja café-tyylit elivät rinnakkain aina 1930-luvulle asti, jolloin café-tyyli oli sulautunut uuteen yhdistelmätyyliin, rebetikaan. 1930-lukua sanotaan rebetikan klassiseksi kaudeksi, jolloin rebetika tuli kaupallisten levytysten myötä tutuksi Kreikan suurimpien kaupunkien asukkaille. Tätä rebetikan kukoistuskautta ei kestänyt pitkään, sillä Metaxasin diktaattorikautena 1936-1941 turkkilaisia kulttuuripiirteitä yritettiin hävittää, ja turkkilaisvaikutteiset rebetikalevytykset joutuivat tiukkaan sensuuriin. Toisen maailmansodan saksalaismiehityksen aikana rebetikaa ei levytetty ja 1940-luvun lopulla käydyn sisällisodan aikana sensuurilait otettiin jälleen käyttöön (Smith 1989, 189). Vasta 1950-luvulla rebetika sai laajan ja heterogeenisen yleisön, mutta tuolloin siitä oli tullut varsin toisenlaista musiikkia kuin mitä se oli ollut 1930-luvulla.

Kolmas rebetikaan ja erityisesti sen kitaratyyleihin vaikuttanut perinne on länsimainen musiikki². Voikin sanoa että, 1930-luvun rebetikassa yhdistyvät itämainen modaalisuus ja sen esityskäytännöt sekä eräät länsimaisen musiikin tyylipiirteet ja esityskäytännöt. Ehkä tärkeimpänä rebetikan musiikkityylin muuttumiseen vaikuttaneena tekijänä pidän länsimaista sointuharmoniaa ja duurimollitonaliteettia.

Yksi tapa lähestyä rebetikan länsimaistumisprosessia on analysoida laulujen harmonisia rakenteita ja erityisesti säestyssoitinten, kuten kitaran soittotyyliä. Koska kitara on rebetikamusiikin pääasiallinen säestyssoitin, kitaransoittotyylin muutokset kuvastavat länsimaisen musiikin vaikutusta Kreikassa. Ennen 1930lukua teké-tyylissä kitaransoittoon sovellettiin esimerkiksi turkkilaisen ud-luutun soittotekniikoita, mutta 1930-luvulta lähtien kitaraa käytettiin yhä enemmän sointusoittimena (Spourdalakis haast. 1992).

Kitaratyylin muutokset eivät vielä 1930-luvulla vaikuttaneet rebetikan luonteeseen, mutta sodan jälkeen ja erityisesti 1950-luvulla länsimaistuminen oli jo selvempää. En väitä, että kitara aiheutti tämän muutoksen, mutta muutoksen airut se kuitenkin oli.

\section{Rebetikakitara}

Hristos Spourdalakisin (haast. 1993) mukaan Kreikassa on rakennettu ainakin 1800-luvun lopulta saakka akustisia tasakantisia teräskielisiä kitaroita. Näiden nykyään rebetikakitaroiksi kutsuttujen soitinten rakentajat muodostavat kolmen sukupolven mittaisen opettaja-oppilas -ketjun.

2) Esimerkiksi Richard Middleton (1990, 12-14) painottaa länsimaisen musiikin vaikutusta. Länsimaistumisprosessi on ollut merkittävin asia koko maailman musiikinhistoriassa viimeisen kahdensadan vuoden aikana. 
Dimitris Murginos rakensi kitaroita vuosina 1899-1935. Murginosin oppilas Aris Aparthian aloitti kitaranrakennuksen noin vuonna 1935 ja lopetti 1980-luvun lopussa. Hristos Spourdalakis, jolla on tällä hetkellä soitinverstas Pireuksessa oppi kitaranrakennuksen puolestaan Aparthianilta.

Hristos Spourdalakis kertoo Dimitris Murginosin olleen tämän vuosisadan alkupuoliskolla Kreikan ainoa soitinrakentaja, joka rakensi buzukien ohella myös kitaroita. Jos tämä pitää todella paikkansa, kaikki muut tuohon aikaan käytössä olleet kitarat oli tuotu Kreikkaan ulkomailta, lähinnä Italiasta, Espanjasta, Yhdysvalloista ja Saksasta. Spourdalakisin mukaan rebetikamuusikot kuitenkin suosivat Murginosin ja Aparthianin kitaroita. Nykyään Kreikassa on toki useampia kitaranrakentajia ja rebetikakitaran malli on muidenkin rakentajien tiedossa (ibid).

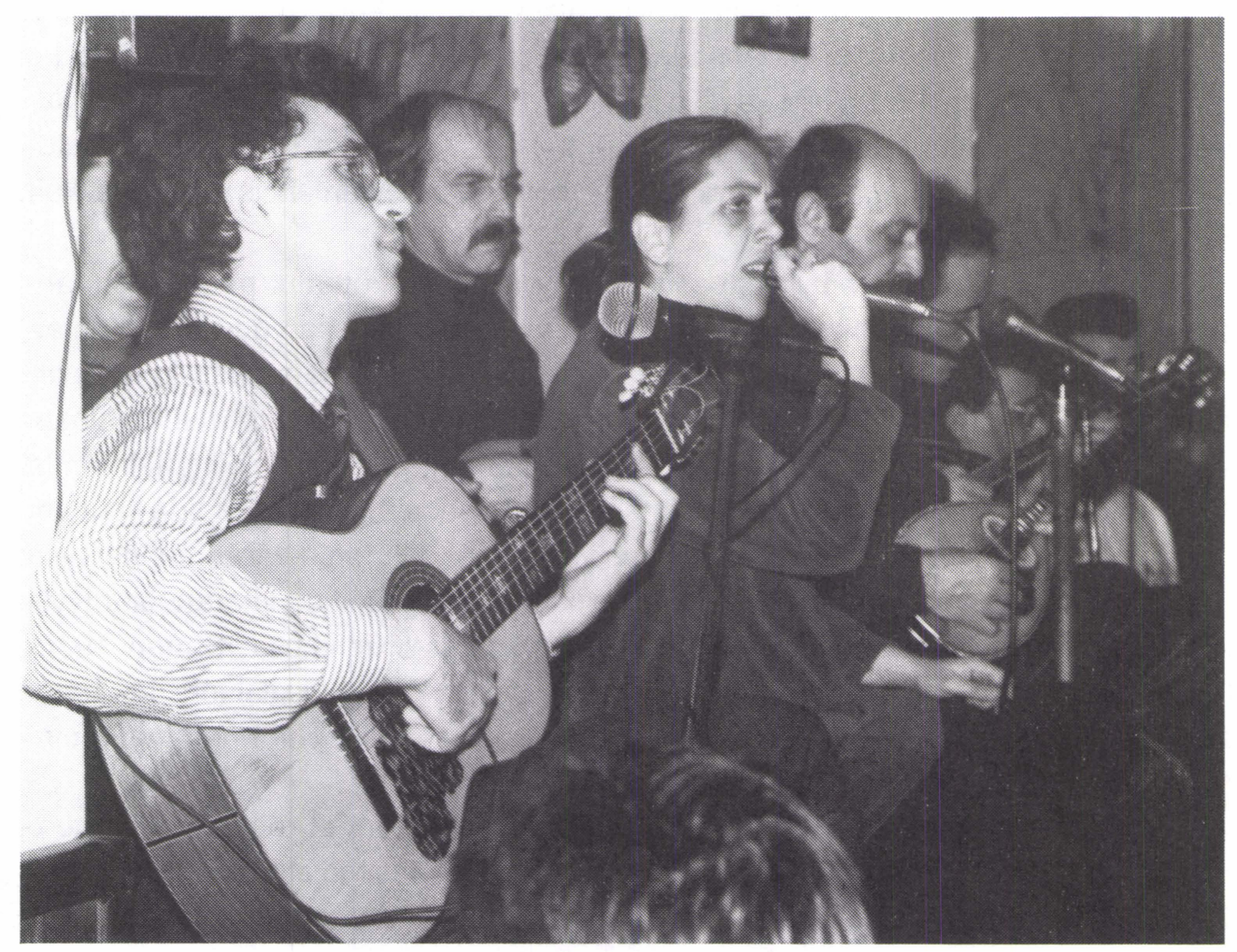

Kuva 1. Hristos Spourdalakisin vuonna 1992 rakentama rebetikakitara. Kitaran mitat ovat: kaikukopan leveys 28, $5 \mathrm{~cm} \times 24,5 \mathrm{~cm} \times 37 \mathrm{~cm}$; Syvyys $10 \mathrm{~cm}$; pituus $48,2 \mathrm{~cm}$; reiän halkaisija $9 \mathrm{~cm}$; kaulan pituus $44,5 \mathrm{~cm}$; kaulan ja kaikukopan yhteispituus $98 \mathrm{~cm}$.

Yksi tärkeimmistä kitaran sointiin vaikuttavista tekijöistä on kitaran kannen alapuolen rimoitus. Rimojen avulla säädellään kannen värähtelyä sen vahvistaessa kielten tuottaman äänen. Rebetikakitaran rimoitus (ks. kuva 2) tuottaa voimakkaan ja kantavan äänen, joka on hyvin erityyppinen kuin esimerkiksi amerikkalaismallisissa teräskielisissä kitaroissa. 
Kitaran rimoituksen perusteella on myös mahdollista jäljittää soittimen rakenteellisiä esikuvia. Rebetikakitaran rimoituksen esikuvat löytyvät ennemminkin 1800-luvun Italiasta ja Ranskasta kuin kitaran varsinaisesta alkuperämaasta, Espanjasta $^{3}$. 1800-luvun italialaisen ja ranskalaisen kitaran rimoitus muistuttaa rebetikakitaran rimoitusta yksinkertaisine poikkirimoineen ${ }^{4}$. Lisänä rebetikakitarassa on poikittainen bassopalkki kahden riman välissä tallan alapuolelle juuri bassokielien kohdalla.

Yksi teräskielisen rebetikakitaran erikoisuuksista on se, että siinä on käytetty espanjalaisen Antonio de Torresin (1817-92) kehittämää tallaa. Torresin tallassa kielet sidotaan solmulla suoraan tallaan eivätkä ne

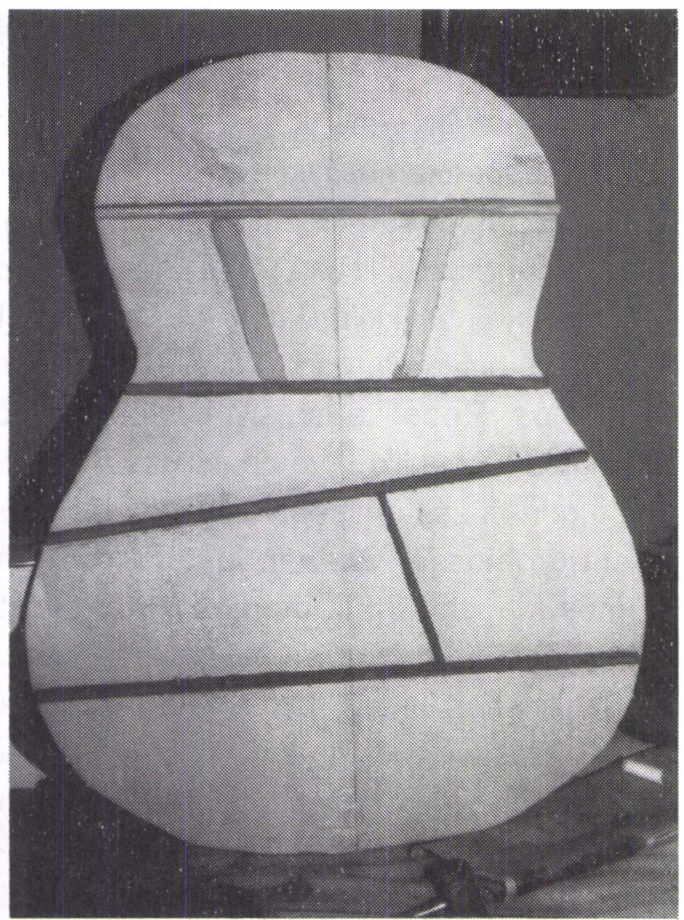

Kuva 2. Rebetikakitaran rimoitus kulje kannen läpi (ks. kuva 4). Syy tähän on äänen voimakkuuden lisääminen ja äänen kantavuuden parantaminen. Useimmiten teräskielisten kitaroiden kielet kiinnitetään tallaan tapeilla (ks. kuva 3). Tällaista kieltenkiinnitysmenetelmää käytettiin vielä viime vuosisadalla myös suolikielisissä kitaroissa. 1900-luvun vaihteessa se jäi melkein yksinomaan teräskielisiin kitaroihin Torresin kehittämän tallan yleistyessä ${ }^{5}$.

Kuva 3. Tappitalla (Lähde: Denyer 1954).
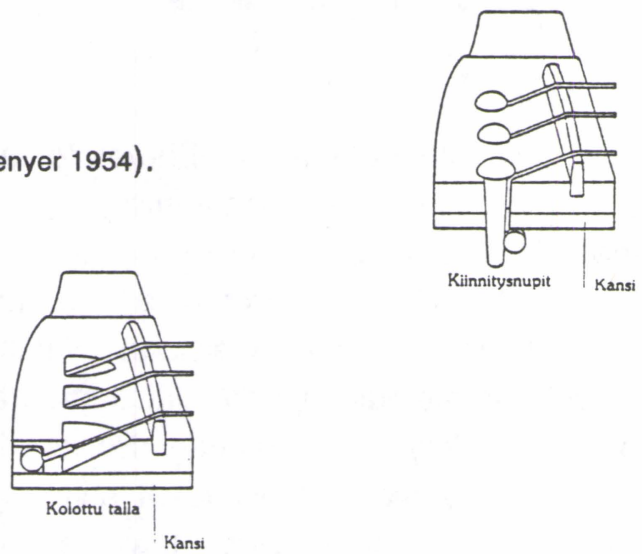

Kuva 4. Rebetikakitaran talla (Lähde: Denyer 1954).

3) Nykyään yleisimmin käytetty ei-teräskielisen kitaran kannen rimoitus on juuri espanjalaista alkuperää.

4) Samankaltainen rimoitus löytyy esimerkiksi ranskalaisesta René Lacôte -kitarasta vuodelta 1852 (ks. Evans 1977, 53-54).

5) Nykyään vastaavanlainen talla on käytössä lähes kaikissa klassisissa eli nailonkielisissä kitaroissa. 
Modaalisuudelle rebetikassa voi löytää esikuvia eri lähteistä (ks. Manuel 1989, 75-76). Rebetikamusiikkiin ovat vaikuttaneet itäiset musiikkikulttuurit ja niiden esityskäytännöt: bysanttilainen kirkkomusiikki, osmanien taidemusiikki ja kreikkalainen kansanmusiikki sekä Vähä-Aasian populaarimusiikki (Einarsson 1987, 41-44).

Rebetikamusiikkiin liittyy itäisille musiikkikulttuureille tyypillinen moodijärjestelmä. Läheisimmät esikuvat ovat turkkilainen makam ja bysanttilaisen kirkkomusiikin ihos. Rebetikamuusikot nimittävät käyttämiään moodeja sanalla dromos ${ }^{6}$. Dromosien säveliköt voidaan usein kirjoittaa länsimaiseen tapaan asteikkoina, mutta niiden esittämiseen liittyy karakteristisia melodiakulkuja (ks. esim. 3a ja 3b). Toisia dromoseja voidaan ajatella enemmän asteikkoina kuin toisia. Esimerkiksi dromos madzore ja ja dromos minore vastaavat duuri- ja molliasteikkoja, ja niitä käytetäänkin rebetikassa hyvin samaan tapaan kuin niiden länsimaisia esikuvia.

Rebetikaan liittyy myös itäisille musiikkikulttuureille tyypillinen rytmimoodien käyttö. Esikuvina ovat jälleen osmanien taide- ja populaarimusiikki, johon kuuluu rytmimoodijärjestelmä usul. Kreikasssa ovat käytössä Anatoliassa ja Balkanilla yleiset epätasajakoiset tahtilajit kuten 9/4 4+5 jakautuvia 9-jakoisia rytmimoodeja ovat karsilamas (ks. esim. 8) ja zeibekiko (ks. esim.15 ja 17), joista edellinen on nopea ja jälkimmäinen hidas. Turkkilainen vatsatanssirytmi, tsifteteli (esim. 1) siirtyi rebetikaan café-aman -tyylin vaikutuksesta. Se tuli erittäin suosituksi Kreikassa samoin kuin serbialainen teurastajantanssi, hasapiko (ks. esim.12).

Esimerkki 1 Turkkilainen vatsatanssirytmi tsifteteli.

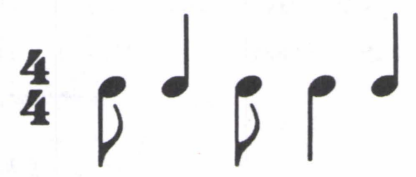

Modaaliseen musiikkiin liittyy olennaisesti heterofoniaksi kutsuttu esityskäytäntö. Heterofonia merkitsee soinnutonta moniäänisyyttä, jossa sävelmää esitetään eri soittimin samanaikaisesti sekä muuntamattomana että hieman muunneltuina versioina (Cooke, 1980, 537). Heterofoniaa voi myös lähestyä erottamalla melodialinjan ja melodian käsitteet toisistaan. Habib Hassan Touman mukaan monodisessa musiikissa melodialinja on soittajien tunteman melodian ideamuoto, kun taas melodia on sen käytännön toteutus (Powers 1988, 204).

Käytännössä rebetikayhtyeet yhdistelevät soitossaan melodioiden heterofonista soittoa sekä sointujen soittoa. Rebetikayhtyeen eri soittimille nämä tehtävät jakautuvat suunnilleen seuraavasti: melodiasoittimilla esitetään heterofonisesti laulu- tai jotain muuta melodiaa kun taas säestyssoitinten soittajat kuten kitaristit ja haitaristit yhdistelevät enemmän tai vähemmän sekä heterofonista soittotapaa että laulun säestämistä soinnuin (vrt. Einarsson 1987, 56-57).

6) Suom. tie. 
Rebetikamusiikin kitarasäestysten analyysin apuna käytän kolmea peruskäsitettä:

1) Modaalisen monofonian käsitteellä tarkoitetaan modaalista musiikkia, joka perustuu sävellyksen perusideana olevaan yhteen lineaariseen ja modaaliseen melodiaan. Esitystilanteissa perusmelodiaa muunnellaan usein heterofonisesti. Tällaista musiikkia on esimerkiksi osmanien taide- ja populaarimusiikki.

2) Soinnullisen harmonian käsitteellä tarkoitetaan musiikkia, joka hahmottuu harmonioidensa avulla. Tällaista on esimerkiksi länsimainen homofoninen musiikki johon liittyy funktionaalinen harmonia (Peter Manuel 1991, 70-71).

3) Modaalisen harmonian käsitteellä tarkoitetaan musiikkia, jossa modaalinen melodia on soinnutettu. Se on siiis kahden edellisen musiikin hahmotus- ja esitystavan yhdistelmä (ibid).

Olennaista modaalisen harmonian ja modaalisen melodian suhteessa on se, että vaikka melodioita säestetään soinnuin ja vaikka melodian säveltäjälläkin on saattanut olla tietyt soinnut mielessään, melodiat ovat kuitenkin modaalisia ja täysin hahmotettavia ilman sointusäestystä.

Modaalisen musiikin soinnuttaminen toimii eri periaatteiden mukaan kuin soinnullinen harmonia. Modaalisessa harmoniassa sointufunktiot eroavat länsimaisen funktionaalisen harmonian käytännöistä. Sointuliikkeitä eivät sido niin tarkat hierarkiset järjestelmät kuin länsimaisessa funktionaalisen harmoniassa vaan sointujen valinta tapahtuu pääasiassa melodian liikkeiden mukaan. Yhteistä näiden käytäntöjen välillä on kuitenkin se, että molemmissa soinnut pyritään rakentamaan melodian sävelikön mukaan.

Rebetikalaulujen soinnutuksessa käytettyjen sointujen määrä vaihtelee dromoseissa. Dromosten säveliköistä ei välttämättä pysty muodostamaan sen säveliä muuttamatta länsimaisen soinnullisen harmonian mukaisia sointuja samoille asteille kuin duurimolli-tonaliteetissa. Esimerkiksi länsimaisessa duurimolli-tonaliteetissa tärkeää V:n asteen dominanttitehoista sointua ei voi muodostaa kaikkien dromosten säveliköistä. Spourdalakisin (haast. 1992) mukaan 1930-luvun rebetikakappaleita soinnutettiin mahdollisimman yksinkertaisilla soinnuilla, lähinnä duuri- ja mollikolmisoinnuilla. Myös dominanttiseptimisointua käytettiin, jos se sopi dromosin sävelikköön. Esimerkiksi dromos oussakissa ${ }^{7}$ (esim. 2) duuri- ja mollikolmisointuja voidaan rakentaa kuudelle asteelle: Dm (i aste), Eb (II aste), F (III aste), Gb (IV aste), B (VI aste) ja Cm (vii aste) (ks. esim. 3). Kaikkia mahdollisia sointuja ei kuitenkaan käytetä vaan tietyt soinnut ovat vakiintuneet melodioiden säestyksiin. Dromos oussakissa tällaisia ovat I, II, IV ja vii asteen soinnut.(ibid)

Joidenkin dromosien mukaisia melodioita ei ole mahdollista soinnuttaa kuin muutamalla soinnulla niiden hankalan intervallirakenteen vuoksi. Tällainen on esimerkiksi dromos segâh (esim. 4), joka soinnutetaan vain muutamalla soinnulla, D:llä (I aste), Gm:llä (IV aste) ja A:lla (V aste).

7) Olen kirjoittanut vertailun helpottamiseksi kaikkien dromosien säveliköt d-pohjaisiksi. 
Esimerkki 2 Dromos oussak.

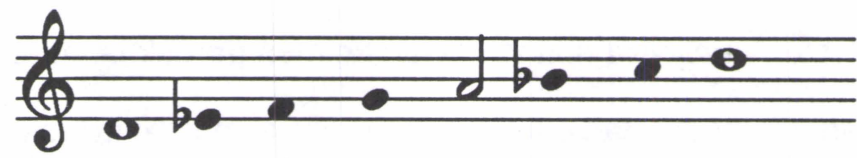

Esimerkki 3 Dromos oussakin sävelikölle rakentuvat duuri- ja mollikolmisoinnut.

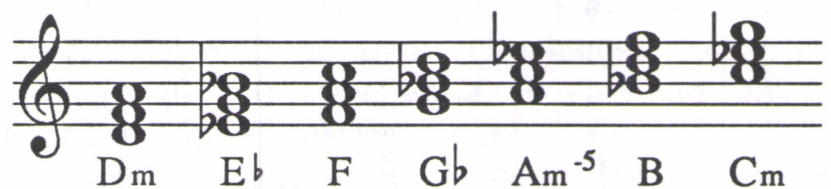

Esimerkki 4 Dromos segahin sävelikölle rakentuvat soinnut.

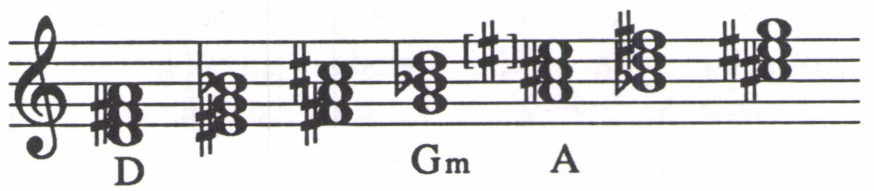

Toinen perusta soinnutukselle modaalisessa harmoniassa melodian lisäksi ovat moodeille tunnusomaiset stereotyyppiset kadenssimotiivit ja niihin käytännön kautta vakiintuneet soinnut. Näissä kadensseissa esiintyvät dromosien tärkeimmät soinnut. Dromos oussakissa tällainen kadenssi on sointutehoiltaan ${ }^{8} \mathrm{i}(\mathrm{Dm})$ bvii (Cm) - i (Dm) (esim. 5a ja 5b). Myös säestyksinä käytettyihin bassomelodioihin voi liittyä tällaisia vakiintuneita käytäntöjä. Tällainen on esimerkin 5b bassomelodian yläjohtosävel es, jota ei soinnuteta bll asteen soinnulla. Tämän sävelen voi tulkita myös bvii asteen terssikäännökseksi (Spourdalakis haast. 1992)

Esimerkki 5a Dromos oussakille tunnusomainen stereotyyppinen kadenssimotiivi.

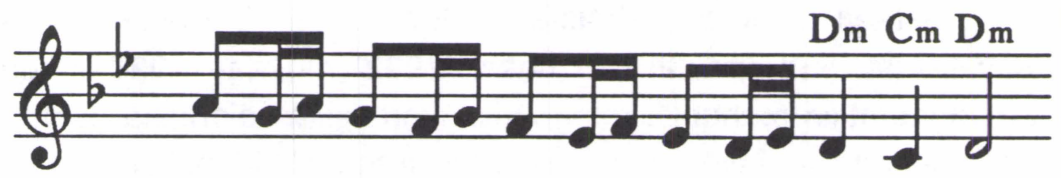

Esimerkki 5b Dromos oussakille tunnusomainen stereotyyppinen kadenssimotiivi.

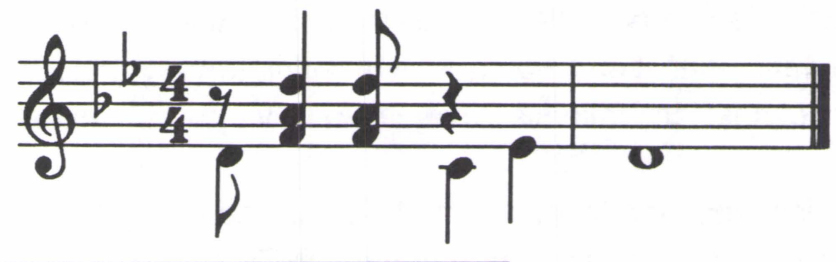

8) Tuodakseni paremmin esille modaalisen harmonian ja länsimaisen funktionaalisen harmonian välisiä eroavuuksia, käytän sointujen analyysissä astemerkintää, vaikka se onkin kehitetty duurimollitonaliteettia varten. Käyttämäni astemerkinnät ovat siis duuri- tai mollipohjaisia, joten esimerkiksi dromos oussakissa asteikon seitsemäntenä asteena olevaa sävel c jo valmiiksi alennettu jos sitä verrataan harmoniseen molliin. Merkintä bvii tarkoittaa siis c-molli sointua, eikä ces-molli sointua. 
Modaalisen harmonian stereotyyppiset kadenssit saattavat joissain dromoseissa muistuttaa länsimaisessa soinnullisessa harmoniassa käytettyjä kadensseja. Esimerkiksi Dromos rastissa (esim. 6) stereotyyppinen kadenssi on sointutehoiltaan I(D) - V (A) - I (D) (esim. 7).

Esimerkki 6 Dromos rast.

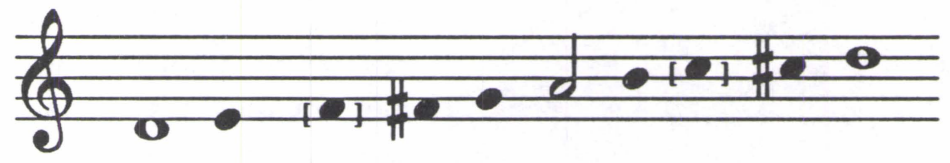

Esimerkki 7 Dromos rastille tunnusomainen stereotyyppinen kadenssimotiivi ja sen soinnuttaminen.

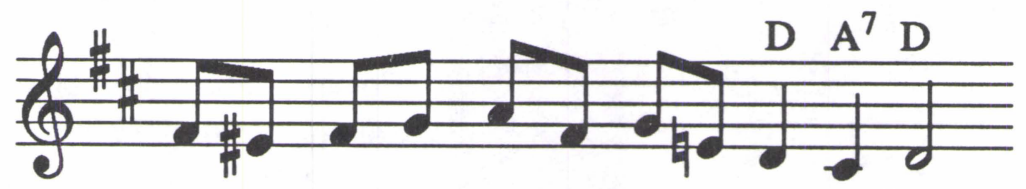

Kolmas modaalisessa harmoniassa käytetty soinnutuksen perusta on Kreikan ja Turkin modaalisessa kansanmusiikissa käytetty tapa vaihtaa bordunasävelenä ollutta moodin pohjasäveltä ilman että moodi vaihtuu. Tällaisen käytännön mukaan säestyssoittimilla saatetaan soittaa vaihtuvien pohjasävelten päälle myös sointuja. Modaalisen melodian soinnuttamista ei voi aina pitää yksinomaan länsimaisen musiikin vaikutuksena (Manuel 1989, 75). Erityisen mielenkiintoisia ovat ne rajatapaukset, jolloin modaalinen melodia on soinnutettu vain muutamalla soinnulla. Tällöin soinnutuksen alkuperä voi olla lähtöisin joko länsimaisesta musiikista tai vaihtuvien pohjasävelten soinnuttamiskäytännöstä tai mieluiten molemmista yhdessä.

Rebetikamusiikista voi löytää myös duurimollitonaliteetin mukaista soinnutusta. Alkuperältään länsimaisten dromos madzoren ja dromos minoren soinnuttaminen ei luonnollisesti eroa länsimäisesta käytännöstä.

On vaikeaa sanoa, miten länsimaisen musiikki ja erittyisesti soinnullinen ajattelu on vaikuttanut rebetikassa ja sitä edeltäneissä tyyleissä ennen 1930-lukua. Manuelin $(1991,76)$ mukaan länsimainen musiikkitraditio on jo 1800-luvulta lähtien vaikuttanut Balkanin alueella. Myös eräissä Konstantinopolissa vuonna 1911 tehdyissä kreikkalaistyylisissä levytyksissä voi kuulla kitaran ja haitarin säestävän laulua soinnuin (MBI CD 119: 17-18).

\section{Rebetikamusiikin kitaratekniikka ja soittotyylit}

Rebetikamusiikissa käytetyistä kitaransoittotekniikoista voisi mainita kaksi erityistekniikkaa:

Rebetikan kitaransoittotyyliin kuuluu soittaa bassoäänet plektran avulla ns. 
apojando-tekniikalla ${ }^{9}$, jotta bassoäänet saataisiin mahdollisimman lujaäänisiksi ja kantaviksi. Äänten voimakkuutta lisää se, että kaikki plektraniskut soitetaan alaspäisinä iskuina sekä se, että kieltä näpätään tallan läheltä, missä kielten jännitys on suuri (ks. kuva 5).

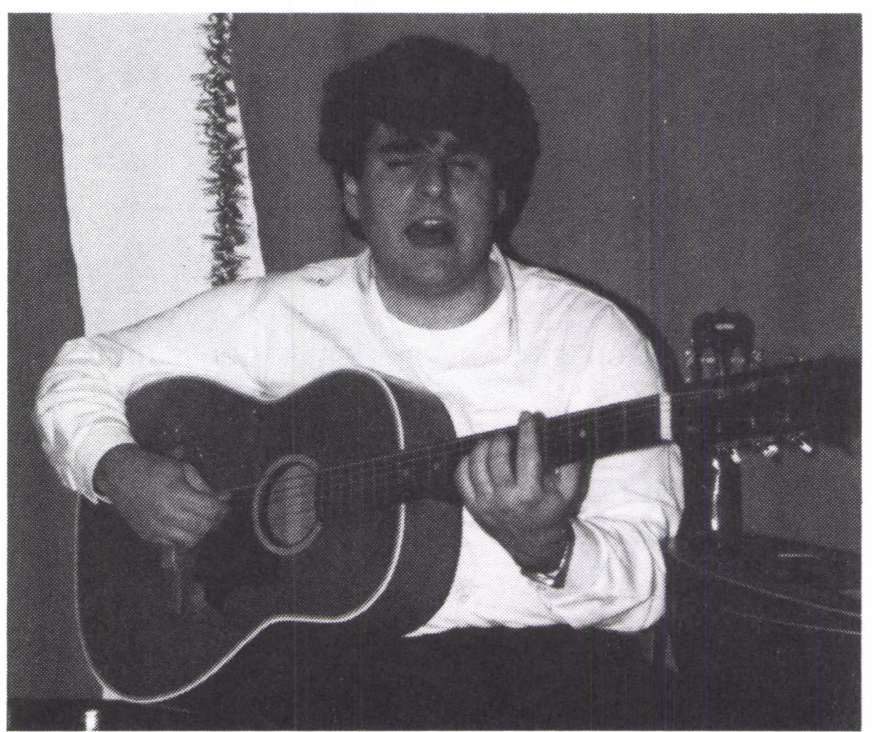

Kuva 5. Rebetikakitaristin oikean käden asento.
Toinen tärkeä tekninen erityispiirre rebetikan kitaransoittotekniikassa on äänten sammuttaminen. Sekä bassoäänet että soinnut soitetaan staccatomaisesti mahdollisimman lyhyinä. Tämä vaati kielten värähtelyn kuolettamista. Yleisin tapa kuolettaa kieli on soittaa vain ns. painettuja ääniä, jolloin riittää että kieltä vasten otelautaa painanut sormi nostetaan kieleltä ylös.

Alunperin kitaran tehtävänä rebetikayhtyeissä ei ollut kappaleiden säestäminen soinnuin. Kitara toimi bassosoittimena, jolla soitettiin sekä bordunaa että turkkilaisen ud-luutun tavoin kaksinnettiin heterofonisesti kappaleen melodialinjoja. Kun kitaristit alkoivat soittaa laulujen säestykseksi myös sointuja, vanha bassoäänten soittotapa ja sointujensoitto yhdistyi yhdeksi soittotyyliksi. (Spourdalakis haast.1992)

Seuraavassa esittelen neljän 1930-luvun rebetikalaulun kitarasäestysten nuotinnokset. Nämä säestykset edustavat tyypillisimpiä rebetikan ns. klassisen kauden kitaratyylejä. 1930-luvun tyylit ovat perustyylejä, jotka pääpiirteissään ovat säilyneet aina näihin päiviin asti. Olen jakanut säestystyylit neljään ryhmään:

1) Bordunasäestys. Ennen kuin teké-tyylin lauluja alettiin varsinaisesti soinnuttaa, oli säestävän kitaristin tehtävänä soittaa kappaleisiin bassoäänet (Spourdalakis haast. 1992). Kitarasäestyksenä käytettiin usein bassokieliltä soitettua bordunaa, jonka päällä laulu- tai buzukimelodia liikkuu. Bordunaääni saadaan aikaan kun kieliä ei kuoleteta näppäysten välillä. Tällöin näpätty ääni saa soida vapaasti ja kielet resonoivat keskenään. Tällainen katkeamaton bordunaääni on hyvin yleinen modaalisen musiikin säestyksenä (vrt. Baines 1980, 637).

Yksi paljon 1930-luvun rebetikassa käytetty tapa on virittää kitaran kielet samoihin säveliin kuin buzukin kielet. Spourdalakisin mukaan tällöin kitaransoittoon sovelletaan buzukin soittotapaa, jossa melodioita soitetaan vain yhdellä kielellä

9) Apojandotekniikassa kieltä näpännyt sormi tai plektra painetaan viereistä kieltä vasten. Näin saadaan kieli värähtelemään pystysuunnassa kitaran kanteen nähden. Tämä tuottaa kannen voimakkaamman resonanssin eli käytännössä voimakkaamman ja kuuluvamman äänen. 
kahden matalimman jäädessä bordunakieliksi ${ }^{10}$. Helpoiten tämä tapahtuu laskemalla kitaran 6. eli matalimman kielen viritys E:stä D:hen. Näin kitaran kolmen alimman kielen viritykseksi saadaan $D, A$, d, buzukin yleisin viritys oktaavia matalammalta.

Toinen 1930-luvulla käytetty tapa soittaa bordunaääniä oli käyttää renessanssi- ja barokkiluuttujen tapaan ylimääräisiä bassokieliä tai niiden tukena jopa ylimääräisiä kauloja. Nämä harppukitaroiksi kutsutut kitarat olivat Euroopassa yleisiä 1800-luvulla, jolloin kitaran äänialaa yritettiin laajentaa eikä kitaran muoto ollut vielä vakiintunut. Harppukitaroita näkee vanhoissa rebetikamuusikoista otetuissa valokuvissa ${ }^{11}$. Myös vanhojen rebetikalevytysten kitaraosuuksia kuuntelemalla voi päätellä käytössä olleen ylimääräisiä kieliä, sillä matalimmat bassoäänet sattavat olla jopa kvintin kitaran normaalia äänialaa matalampia.

Spourdalakis (haast. 1992) kutsuu tämän tyylin mukaista repertoaaria nimellä "the very old songs" tarkoittaen café- ja teké-tyylejä ennen rebetikan klassista kautta 1930-luvulla ${ }^{12}$. Hänen itse soittamansa tätä vanhaa tyyliä esittelevät esimerkkikappaleet sisältävät bordunaäänen.

Rebetikassa bordunasäestyksen tyyliin kuuluu myös kaksintaa tai varioida heterofonisesti melodioita kitaran bassokielillä. Esikuvana tälläisessa soittotavasssa on Spourdalakisin (ibid) mukaan turkkilainen ud-luuttu, jota kitaransoittaja kreikkalaisessa musiikissa usein imitoi.

Esimerkissä 9 on Markos Vamvakarisin kamilieriko Alaniaris. Kappale koostuu neljän tahdin mittaisesta buzuki-introsta ja sitä seuraavasta neljän tahdin mittaisesta lauluosuudesta. Tämä kokonaisuus kerrataan viisi kertaa. Kitaristi ja baglamansoittaja säestävät laulua ja buzukia. Tässä kappaleessa kitaran bordunasäestys on soitettu vapailla bassokielillä, jotka on viritetty buzukin mukaan säveliin $D, A$, d. Säestyksessä käytetään vain dromos houssamin (esim 8) perussäveltä d ja sen kvinttiä a, kamilierikon rytmimoodin mukaan. Lisäksi joka toisen tahdin lopussa on lyhyt kolmen iskun mittainen rytmikadenssi (ks. tahti 2).

\section{Esimerkki 8 Dromos houssam.}

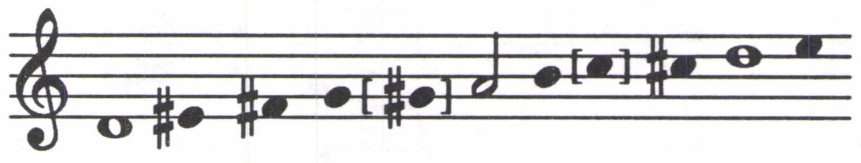

2) Soinnutettu bordunasäestys. Toisena kitarasäestystyylinä on edellisestä bordunasäestyksestä hieman poikkeava variaatio, jota kutsun nimellä soinnutettu bordunasäestys. Tämä säestys (esim 10a) ei eroa perusidealtaan bordunasäestyksestä. Pohjalla soivaan bordunaääneen on yhdistetty kolmi- ja nelisointuja. Eräs länsimaisuuteen viittaava piirre on kuitenkin huomioitava. Dromos

10) Spourdalakis tarkoittanee buzukin vanhaa soittotapaa.

11) Rebetika-aiheisia valokuvia on Elias Petropouloin kirjassa Rebetika Tragoudia (1979).

12) Buzuki- eli teké-tyylin kappaleita ei levytetty Kreikassa ennen vuotta 1933 eikä café-tyyliäkään ennen vuotta 1925 (Smith 1989, 184). 
Jouste

segah-pohjaiseen melodiaan on yhdistetty $\mathrm{V}$ asteen dominanttitehoinen sointu, vaikka sellaista ei ole mahdollista rakentaa dromos segahin säveliköstä sen ääniä muuttamatta.

Esimerkki 9 Markos Vamvakarisin kamilieriko Alaniaris vuodelta 1934 EMI 0621702001 (3) A1. Kitaristina Anestos Delias. Nuotinnos M.J.

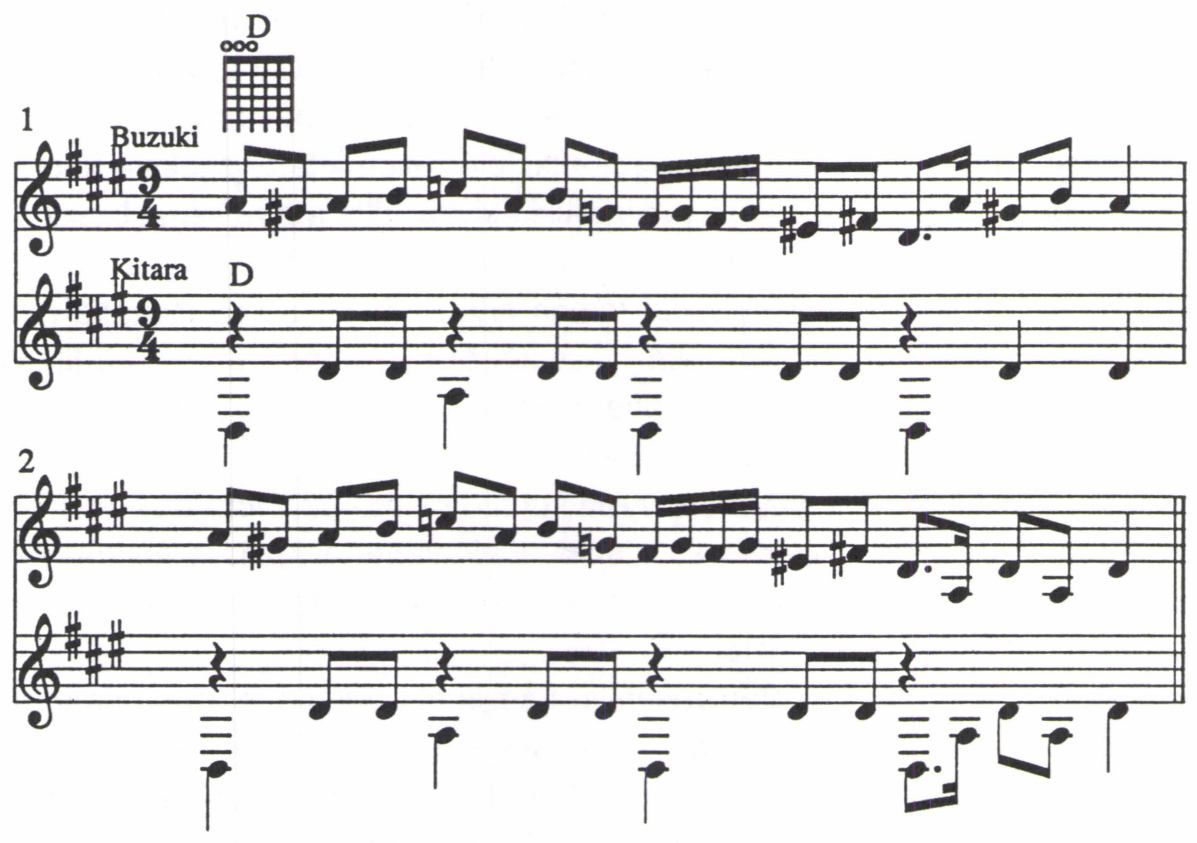

Esimerkki 10a Markos Vamvakarisin kamilieriko Alana Piriotisa vuodelta 1936 (EMI 062-1702001 (3) B6.). Nuotinnos M.J.

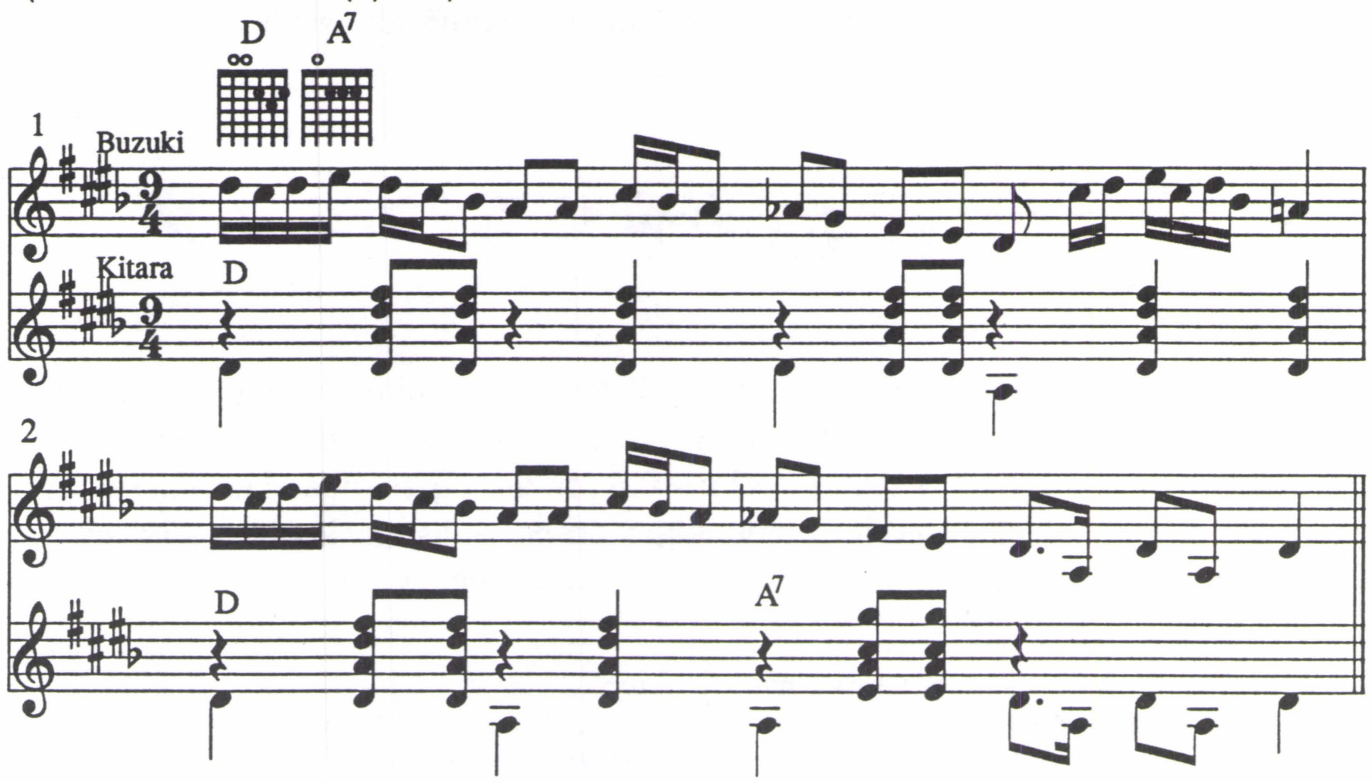


Markos Vamvakarisin kamilierikossa Alana Piriotisa kitara on standardivireessä eli kielet matalimmasta korkeimpaan on viritetty säveliin $E, A, d, g, h, e^{1}$. Sointuotteina tässä säestyksessä käytetään ns. avosointuja, joissa soi myös vapaita kieliä. Kun kieliä ei sammuteta, saadaan soimaan pitkä, yhtenäinen esimerkin 10b mukainen bordunaääni. Tämä yhtenäinen bordunaääni on säestyksen perusidea. Soinnut ovat pikemminkin moodin I asteen ja $V$ asteen sävelten laajennuksia kuin itsenäisiä funktionaalisia kolmi- ja nelisointuja. Bordunaääni katkeaa vain joka toisen tahdin lopussa olevan sointukadenssin ajaksi, joka muistuttaa esimerkki 7:n vastaavaa kadenssia

Esimerkki 10b Kielien ja resonanssin aiheuttama bordunaääni. Nuotinnos M.J.

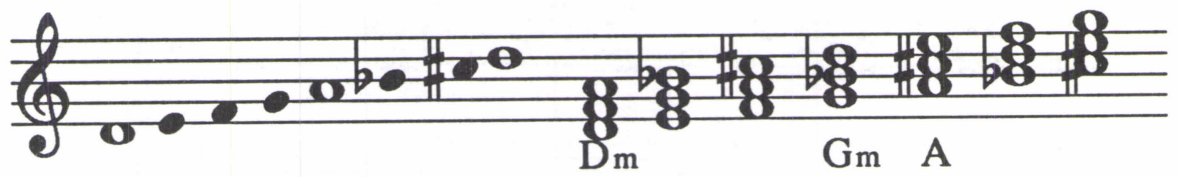

3) Säestys, jossa käytetään sointuja länsimaisen funktionaalisen harmoniaopin tavoin. Tässä säestystyylissä on siirrytty pois bordunan soitosta. Kitaralla soitetaan kolmi- ja nelisointuja sointuottein sekä erillisiä bassomelodioita. Tyyliin kuuluu erotella bassoäänet ja soinnut rytmisesti toisistaan siten, ettei niitä soiteta yhtäaikaa. Bassoäänet soitetaan bassokieliltä ja soinnut diskanttikieliltä. Spourdalakisin (haast. 1992) mukaan tällaisessa soittotavassa kitarassa yhdistyy kaksi soitinta, basso ja kitara. Tyyliin kuuluu myös kaksintaa tai varioida kappaleen melodioita tai soittaa bassomelodiota ja täyteääniä yhdistämään eri sointuja.

Rita Abatsin laulama ja Panajotis Toundasin säveltämä sekä sanoittama hasapiko Garzona vuodelta 1938 (esim. 13) on melodialtaan modaalinen kappale, joka on soinnutettu täysin länsimaisen harmoniaopin mukaan. Soinnutuksessa on käytetty vain i:n, iv:n ja V:n asteen sointuja. Soinnutuksen länsimaistumiseen vaikuttaa luonnollisesti se, että dromos armoniko minore (esim. 11) on sama kuin länsimaalainen harmoninen molli. Toisaalla kappaleessa soitetaan bassomelodioita (ks. tahdit 5-6), jotka noudattavat toista käytettyä dromosta, niavant (esim. 12). Kohdat, joissa olisi ollut pakko käyttää muita kuin i:n, iv:n tai V:n asteen sointuja on jätetty soinnuttamatta. Sointujensoiton sijaan kaksinnetaan kappaleen laulumelodiaa.

Levytyksen kokoonpanossa on laulun lisäsi käytetty melodiasoittimina viulua ja sandouria. Säestyssoittimena on kitara.

Esimerkki 11 Dromos armoniko minore sekä kappaleen Garzona soinnuttamiseen käytetyt soinnut.

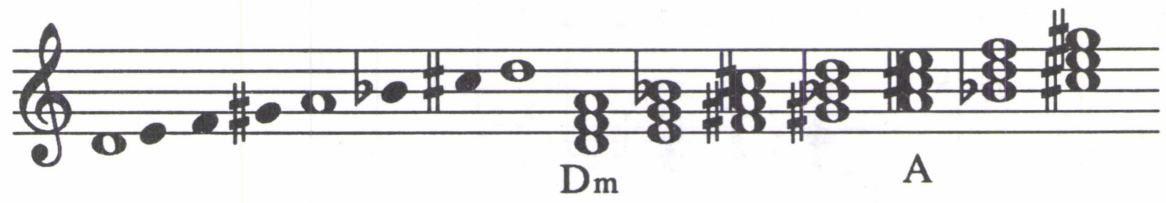


Jouste

Esimerkki 12 Dromos niavent sekä kappaleen Garzona soinnuttamiseen käytetyt soinnut.

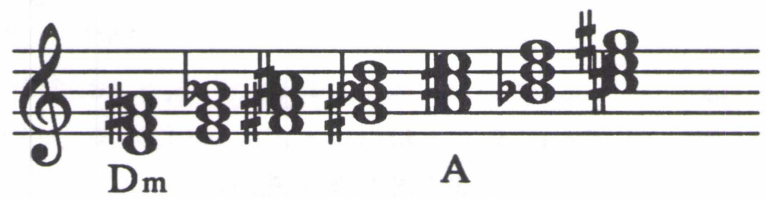

Esimerkki 13 Rita Abatsin laulama ja Panajotis Toundasin säveltämä sekä sanoittama hasapiko Garzona, vuodelta 1938. EFA-Trikont CD 00071 1. Nuotinnos M.J.
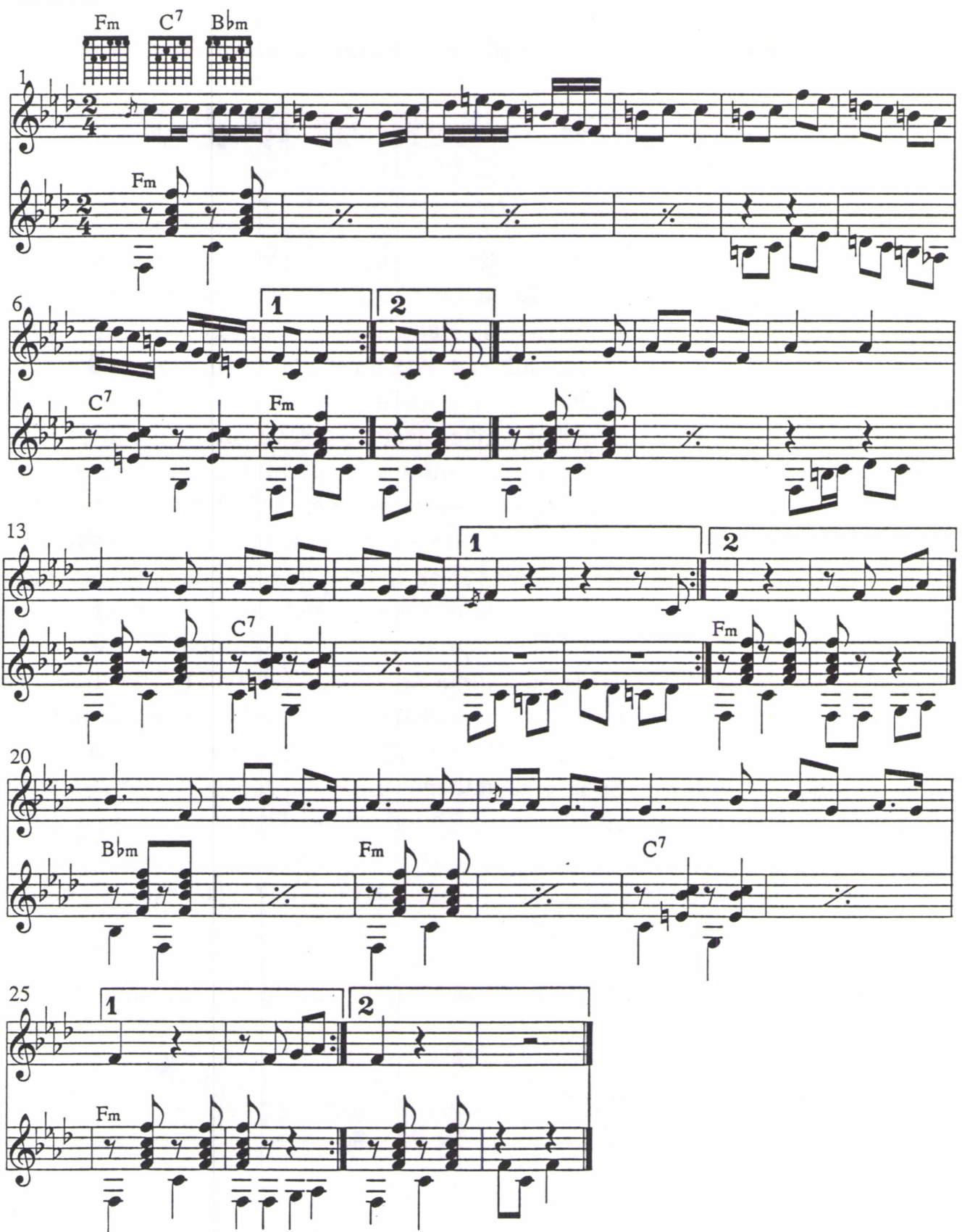
4) Säestys, jossa käytetään modaalista harmoniaa. Modaalisessa harmoniassa sointufunktiot eroavat länsimaisen funktionaalisen harmonian käytännöistä. Sointuliikkeitä ei määrää sointujen hierarkinen järjestelmä, vaan niiden valinta tapahtuu melodian liikkeiden mukaan. Lisäksi sointujen valintaan vaikuttavat stereotyyppiset kadenssimotiivit ja niihin vakiintuneet soinnut. Vassilis Tsitsanisin kamilierikon Fadazes san Prikipessan (esim.15) melodia on soinnutettu kolmella soinnulla: D:lla (I aste), Cm:lla (bvii aste) sekä Gm:lla (iv aste). Käytetyt soinnut sopivat dromos hidzazin sävelikköön (esim. 14).

Esimerkki 14 Dromos hidzaz sekä kappaleen Fandazes san Prigipessa soinnuttamiseen käytetyt soinnut.

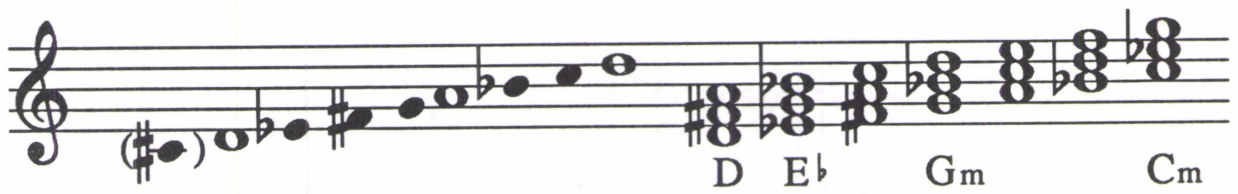

Esimerkki 15 Vassilis Tsitsanisin kamilieriko Fandazes san Prigipessa (Margo 8150). Nuotinnos M.J.
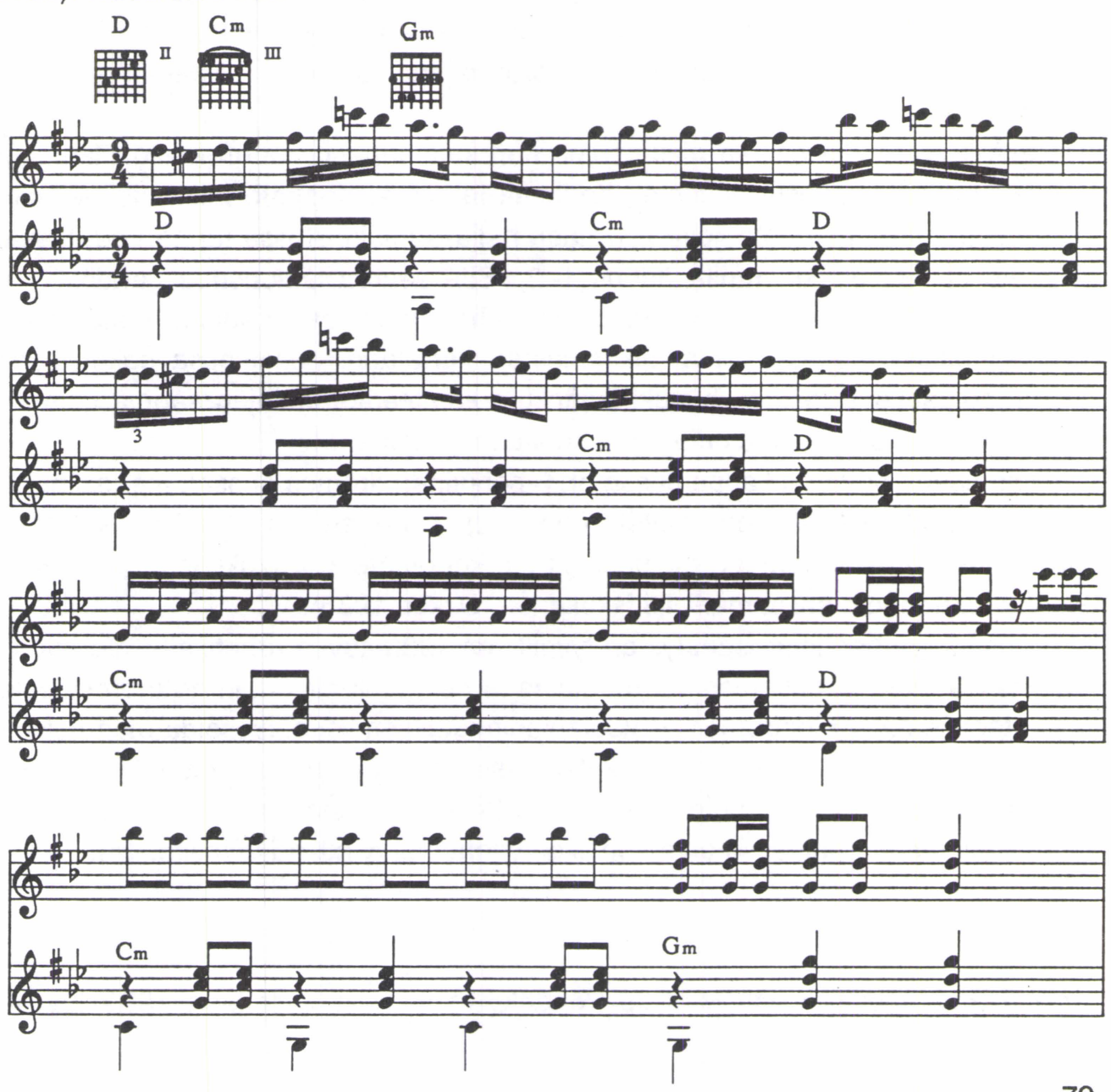
Kappaleen kitarasäestys muodostuu vuorottelevista bassoäänistä ja soinnuista. Käytännössä rebetikakappaleiden soinnuttaminen modaalisen harmonian mukaan eroaakin länsimaisen funktionaalisen harmonian mukaisesta soinnutuksesta vain sointuvalintojensa puolesta. Tyylillisesti ja soittoteknisesti säestykset ovat molemmissa tapauksissa samankaltaisia.

Fadazes san Prikipessa alkaa viiden tahdin mittaisella introlla, jossa melodiaa soittavat sekä buzuki että baglama (ks. tahdit 1-5). Introa seuraa neljän tahdin mittainen lauluosuus (ks. tahdit 6-9).

\section{Esimerkki tyylin muutoksesta. Kaksi Mes tis Pendelis ta vouna -levytystä}

\section{Rebetikan klassisen kauden versio}

Jannis Papajoannoun zeibekiko Mes tis Pendelis ta vouna on tyypillinen 1930luvun ns. klassisen kauden rebetikakappale, jonka laulaja Stratos Pajoumzis levytti ensimmäisen kerran vuonna 1939 (esim. 17). Kappaleen tekstissä kerrotaan matkasta Ateenan lähistöllä olevalle Pendelisvuorelle, jolle kertoja nousee tapaamaan kuoleman jumala Karonia. Vuoren rinteillä mäntyjen lomassa hän sitten tapaakin etsimänsä kuoleman, mutta Kharon ei suostu enää päästämään kuolevaista takaisin.

Tällä levytyksellä soittaa ajalle tyypillinen kokoonpano, johon kuuluu laulajan ja buzukin lisäksi säestyssoittimet, baglama ja kitara. Kappale rakentuu laulajan ja buzukin vuoropuhelusta, joka kerrataan neljässä säkeistössä tarinan edetessä. Kappale alkaa buzuki-introlla (tahdit 1-2). Sitä seuraa lauluosuus (tahdit 3-7), jonka aikana buzuki kaksintaa laulumelodiaa heterofonisesti. Laulusäkeistö koostuu kahdesta säkeestä, joista jälkimmäinen kerrataan. Jokaisessa säkeistössä toisen laulusäkeen jälkeen buzuki ikäänkuin kommentoi laulajan sanoja kertaamalla edellisen säkeen melodian muunneltuna (tahdit 4-5).

Melodisena pohjana kappaleessa on f-pohjainen dromos oussak (ks. esim. 2), jolle on tyypillistä 6. asteen vaihtelu (des - d). Turkkilaiseen musiikkiin viittaava piirre on se, ettei kappaleen melodiassa ole kohotahteja. Buzuki-intro ja -välike alkavat aina tahdin ensimmäisellä iskulla (vrt. Özkan 1985).

Myös kappaleen kitarasäestys on tyypillinen 1930-luvun rebetikalle. Se koostuu bassoäänten ja sointujen vuorottelusta ja osin laulumelodian heterofonisesta kaksintamisesta (vrt. esim. 13). Melodian soinnutuksen voi analysoida modaalisen harmonian mukaan. Soinnulla ei ole itsenäisiä tehoja vaan ne ovat selitettävissä melodian kautta. Käytössä olevat kaksi sointua ovat: i aste (Fm) ja iv aste (Bbm). Rytmimoodina kappaleessa on zeibekikon vanhempi rytmikaava (esim. 16).

1960-luvun versio

Stratos Pajoumdzis levytti Mes tis Pendelis ta vounan uudelleen 1960-luvulla 
(esim. 19) ${ }^{13}$. Kun vertaa uudelleenlevytystä 1930-luvun versioon, voi huomata kappaleen muuntuneen, vaikka laulun esittäjä onkin pysynyt samana. Useat turkkilaiseen musiikkiin viittaavat piirteet ovat hävinneet, ja tilalle on tullut länsimaisen musiikin tyylipiirteitä.

Esimerkki 16 Zeibekikon vanhempi rytmimoodi 1930-luvulta (Holst 1975, 67).

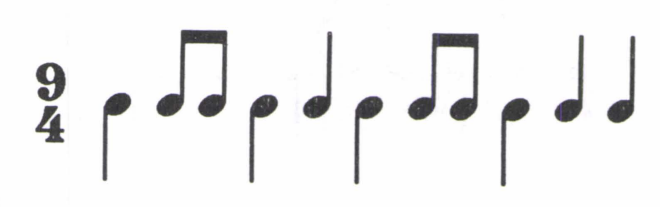

Esimerkki 17 Jannis Papaioannoun säveltämä ja Stratos Pajoumdzisin laulama kappale Mes tis Pendelis ta vouna, vuodelta 1939 (D.P.I. Atheneum EPE K. 6. 558 A3). Nuotinnos M.J.

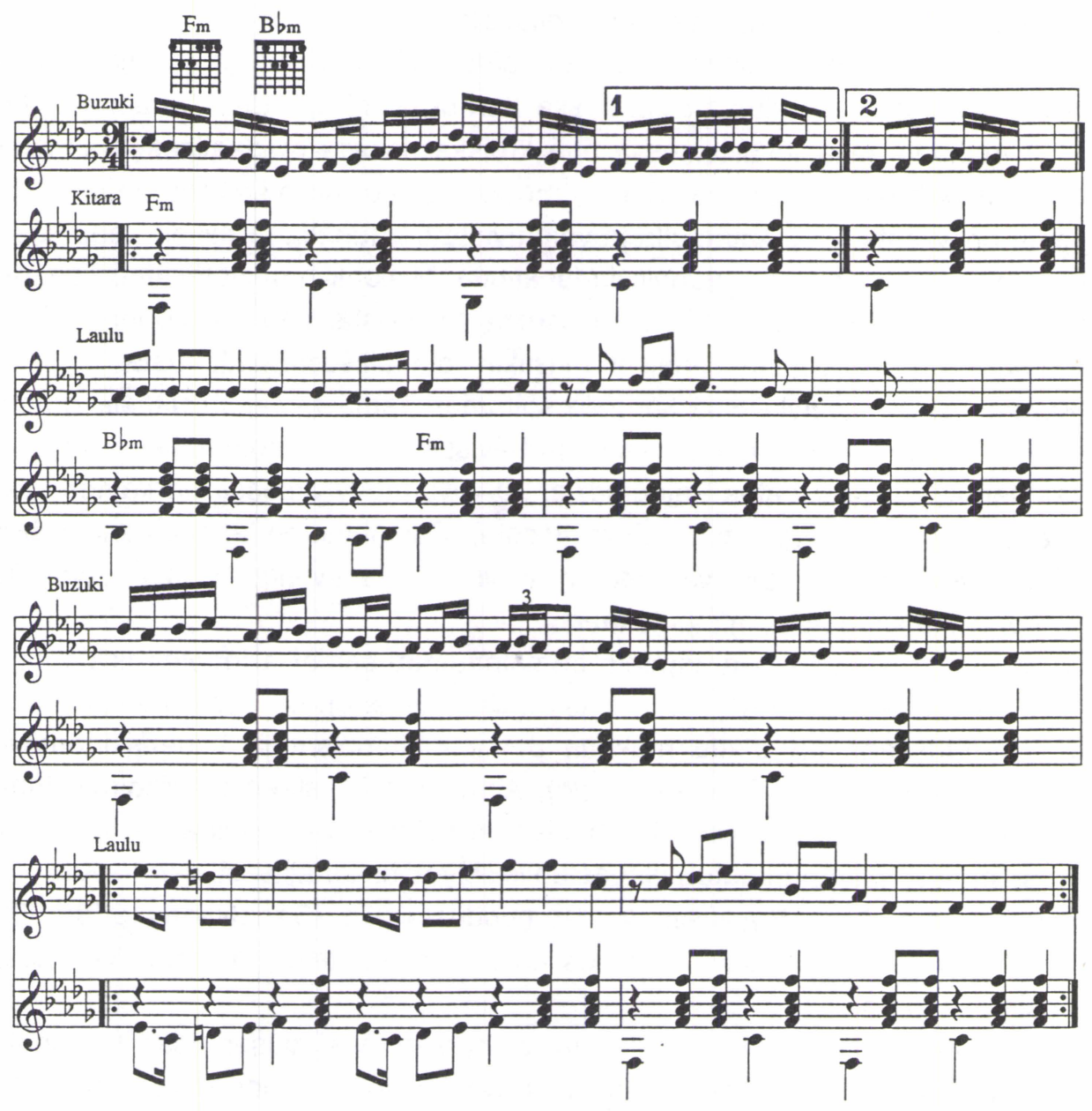

13) Levytys on julkaistu vuonna 1969 mutta kappale on todennäköisesti äänitetty aiemmin. 
Holstin $(1975,67)$ mukaan zeibekikoa on soitettu kahdella eri rytmikaavalla. 30luvun levytyksessä on käytetty vanhempaa rytmikaavaa (esim. 16) kun taas 60-luvun levytyksessä rytmikaava on tanssillisempi, pisteellisine rytmeineen (esim. 18).

Esimerkki 18 Zeibekikon uudempi rytmikaava (Holst 1975, 67).

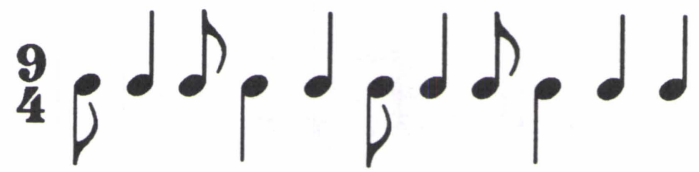

1930-luvun levytyksessä melodiat alkavat tahdin ensimmäiseltä iskulta, kun taas 1960-luvun levytyksessä on käytetty paljon kohotahteja. Kappale alkaa kohotahdilla. Turkkilaiseen musiikkiin viittava piirre on hävinnyt. Kohotahdit ovat luultavasti länsimaista alkuperää. Uudelleenlevytyksessä myös kappaleen tempo on muuttunut 1930-luvun versiota rauhallisemmaksi.

Koska bordunaäänen päälle voidaan lisätä sitä edustava sointu säestyksen idean varsinaisesti muuttumatta ja koska bordunaääni saattaa Manuelin (1989, 75-76) mukaan sekä turkkilaisessa että kreikkalaisessa modaalisessa kansanmusiikissa vaihdella ilman että käytetty moodi vaihtuu, on oleellista tietää milloin kappale on säestetty soinnutetulla ja vaihtuvalla bordunalla ja milloin taas säestetty soinnuin, joilla on sointutehollisia funktioita. Mielenkiintoista tässä on se, että edellinen on lähtöisin itäisestä modaalisesta musiikista, jota on modernisoitu ja jälkimmäisen on peräisin länsimaisen musiikin soinnullisesta ajattelusta.

Kummassakin levytyksessä kappale soitetaan samasta f-pohjaisesta dromos oussakista. Sama säveltaso on ymmärrettävissä, koska kummankin levytyksen laulaa sama laulaja, Stratos Pajoumdzis. 30-luvun levytyksessä on käytetty vain lepotehoisia sointuja Fm (i aste), Bbm (iv aste). Soinnutus on lähellä vanhaa bordunasäestystä, jossa vain vaihdetaan välillä pohjasäveltä, vaikka käytettävä moodi ei tässä kappaleessa muutukaan.

1960-luvun levytyksessä kappale on soinnutettu samoilla lepotehoisilla soinnuilla kuin 1930-luvun levytys: Fm (i aste), Bbm (iv aste). Uutena piirteenä on se, että soinnutukseen on otettu mukaan dominanttitehoiset ja kadenssinomaiset soinnut: Gb (bll aste) ja Ebm (bvii aste). Alennetun II asteen duurikolmisoinnun voi länsimaisen funktionaalisen harmoniaopin mukaan analysoida ns. napolilaiseksi soinnuksi, joka purkautuu i:lle asteelle. Myös historiallisesti sen käyttö liittyy fryygisessä moodissa tyypillisiin lopukemuodostelmiin (Bengtsson 1978, 399). Alennettu vii aste taas kuuluu dromos oussakille luonteenomaiseen kadenssiin (ks. esim. 5a ja 5b).

Toinen seikka, joka viittaa 60-luvun levytyksen länsimaisempaan harmoniaajatteluun, ovat dominanttitehoiset bassosävelet. Huomiota herättävää on yläjohtosävelen ilmaantuminen ennakkosävelenä bassomelodiaan siirryttäessä bll- tai bVII-asteen soinnusta I-asteen sointuun (ks. tahti 1). I asteen sointuun edetään myös vuorottelemalla bassokielillä perusääntä ja kvinttiä kadenssinomaisesti (ks. 
tahti 3). Jos taas samassa soinnussa pysytään tahtiviivan yli, soitetaan usein soinnun dominanttisävel kohosävelenä seuraavalle tahdille (ks. tahti 4).

1930-luvun heterofonisesta käytännöstä on 1960-luvun levytyksessä siirrytty länsimaisempaan ja orkestraalisempaan tyyliin. Buzukilla tai kitaralla ei enää kaksinneta laulun melodiaa vaan esimerkiksi buzuki soittaa vain introssa ja välikkeissä. Mukana on myös harmonikka, joka korvaa 5. tahdin buzukivälikkeen. Buzukiosuudet samoin kuin lauluosuudet ovat melodioiltaan muuttuneet monimutkaisemmiksi. Mukana on myös kontrabasso, jota alettiin käyttää rebetikakokoonpanoissa 1950-luvulla.

Kappaleen pienoismuoto on tiivistynyt 60-luvun levytyksessä, sillä laulun kahta viimeistä säettä ei enää kerrata kuten 1930-luvun versiossa (ks. tahdit 6-7).

\section{Päätelmä}

Kreikkalainen rebetikamusiikki on orientaalin ja läntisen musiikkikulttuurin fuusiomuoto. Rebetikasta löytyviä orientaaliselle musiikkikulttuurille tyypillisiä piirteitä ovat modaalisuus ja esityskäytäntönä oleva heterofonia. Länsimaisen musiikkikulttuurin piirteitä taas ovat harmoninen ajattelutapa ja duurimollitonaliteetti. Nämä kummatkin ovat rebetikassa sekoittuneet modaalisuuteen.

Musiikkikulttuurien fuusio on synnyttänyt rebetikaan länsimaisesta poikkeavan harmonisen ajattelutavan, modaalisen harmonian. Siinä sovelletaan länsimaisen musiikin soinnutustapoja modaaaliseen musiikkiin.

Tärkein rebetikakappaleiden soinnuttamiseen vaikuttava tekijä länsimaisen musiikin ohella on dromosjärjestelmä. Melodian soinnuttaminen perustuu käytetyn dromosin säveliköille. Eräitä dromoseja, kuten dromos segahia ei niiden intervallirakenteen vuoksi ole mahdollista soinnuttaa kuin yhdellä tai kahdella soinnulla. Joillekin dromoseille, kuten esimerkiksi dromos madzorelle on taas mahdollista rakentaa täysin länsimaista käytäntöä vastaava soinnutus. Kuitenkin kappaleiden soinnuttaminen on katsottu tärkeäksi. Esimerkiksi Panajotis Toundasin kappaleessa garzona on soinnuttamisen kannalta vaikeat kohdat jätetty ilman sointuja ja tyydytty kaksintamaan melodiaa.

Tarkastelemalla rebetikan tärkeimmän säestyssoittimen, kitaran 1930-luvun soittotyylejä voi löytää erilaisia soinnullisen säestyksen muotoja, joissa yhdistellään eri tavoin länsimaisia ja turkkilaisia soittotyylejä ja soittotekniikoita. Tällainen on esimerkiksi bordunasäestyksen ja sointusäestyksen sekoitus, soinnutettu bordunasäestys. Myös erilaisten bordunaäänten soittamista helpottavien viritysten avulla on pyritty yhdistelemään näiden kahden musiikkikulttuurin soittotapoja. Vaikka bordunasäestystä ei enää 1930-luvun jälkeen ole juuri käytetty, ovat monet tyylipiirteet yhä eläviä. Yksi tällainen yhdistelmätyyli liittyy heterofoniseen esityskäytäntöön. Vaikka kitaralla pääasiallisesti soitetaankin sointusäestystä, on tyylinmukaista käsitellä yhtäaikaa kappaleen melodiaa heterofonisesti. Myös vanhat ja uudet tyylit voivat sulautua toisiinsa. 
Jouste

Esimerkki 19 Jannis Papaioannoun säveltämä ja Stratos Pajoumdzisin laulama zeibekiko Mes tis Pendelis ta vouna. Julkaistu vuonna 1969. Nuotinnos M.J.
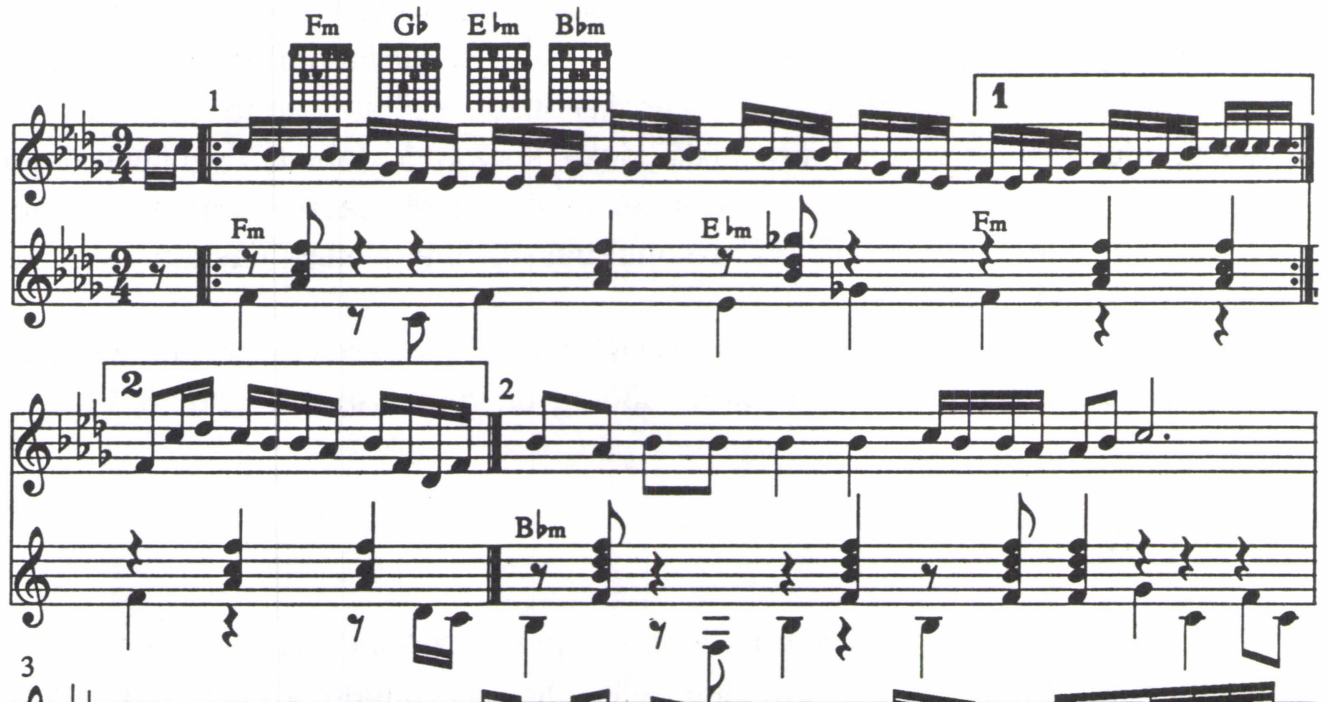

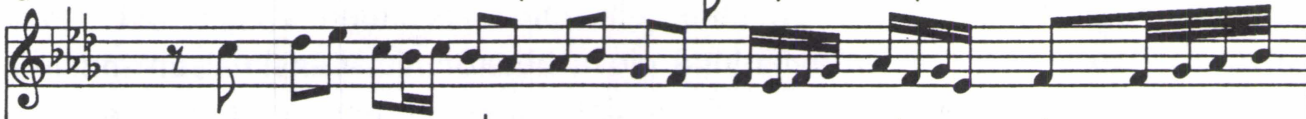

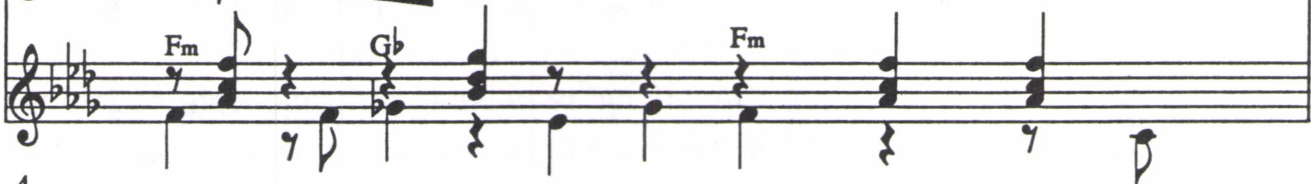

4

(4)

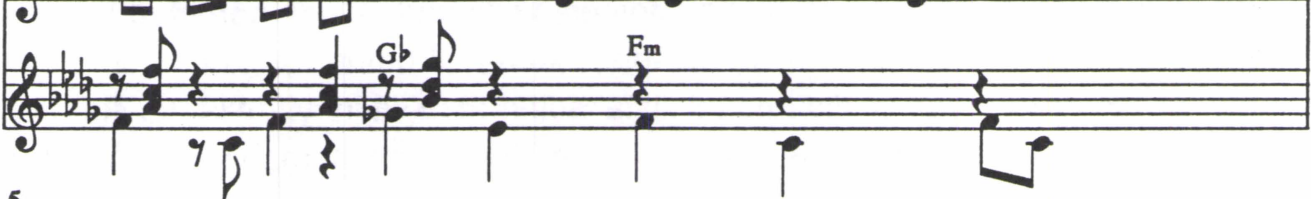

5

(a)

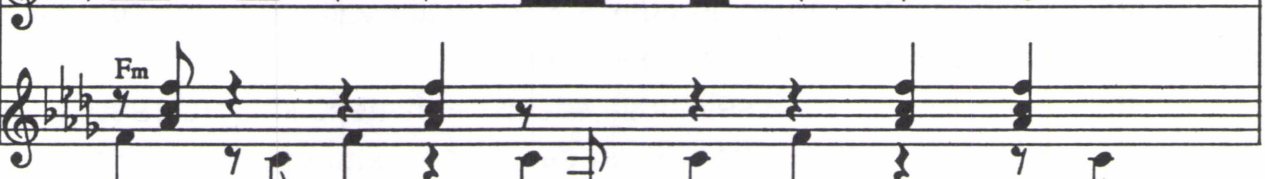

6

$(4)_{0}^{2}+20$ (4) 
Tultaessa lähemmäksi nykyaikaa ovat kuitenkin yhä hienovaraisemmat länsimaisen musiikin elementit tulleet osaksi rebetikan soittotyylejä. Kaikesta huolimatta on rebetikaan sen vaiheikkaan historian aikana muodostunut monia omaleimaisia tyylipiirteitä, joita ei löydy muista musiikkikulttuureista, niin orientaalista kuin myöskään länsimaisesta.

\section{Lähteet}

Kirjalliset:

Baines, Anthony, C: 1980 "Drone" The New Grove Dictionary of Music and Musicians 8, 537. Edited by Stanley Sadie. Macmillian Publishers Limited. London.

Bengtsson, Ingmar: 1978 "Napolilainen sekstisointu." Otavan iso musiikkitietosanakirja 4, 399. Kustannusosakeyhtiö Otava.

Cooke, Peter: 1980 "Heterophony". The New Grove Dictionary of Music and Musicians 8, 537. Edited by Stanley Sadie. Macmillian Publishers Limited. London.

Denyer, Ralph: 1984 Suuri kitarakirja. WSOY, Porvoo-Helsinki-Juva.

Einarsson, Mats: 1987 Grekisk Rebetika. En översiktlig beskrivning av rebetikakulturen och stilistiska iakttagelser av musiken. 60-poängsuppsats vid Musikvetenskapliga Institutionen vid Stockholms Universitet.

Evans, Tom and Mary Anne: 1977 Guitars Music, History, Construction and Players From the Renaissance to Rock. Paddington Press. New York-London.

Holst, Gail: 1989 Road to rembetika. Music of a Greek Sub-Culture. Songs of Love, Sorrow \& Hashish. Denise Harvey \& company. Limni - Athens.

Manuel, Peter: 1989 "Modal Harmony in Andalusian, Eastern European, and Turkish Syncretic Musics." Yearbook for Traditional Music vol. 21, 70-94. New York.

Middleton, Richard: 1990 Studying Popular Music. Open University Press. Buckinham.

Petropoulos, Elias: 1979 Rebetika tragoudhia. Rebetika Songs from the old Greek Underworld. Kedros. Athens.

Smith, Ole L: 1989 "Research on Rebetika. Some Methodologial Problems and Issues." Journal of Modern Hellenism vol.6, 177-190.

1991 "The Chronology of Rebetiko". Balkan and Modern Greek Studies vol.15, 318-324.

Harold Powers: 1988 "First Meeting Of The ICTM Study Gruop On Maqan. " Yearbook For Traditional Music vol. 20 (Part One), 199-218. The International Council For Traditional Music. Library of Conress.

Özkan, Ismail Haki: 1984 Türk mûsikîsi nazariyati ve usûlleri. Kudüm velveleri. Ötüken Nesriyat. Istanbul.

Haastattelut:

Spourdalakis, Hristos: 1992 Haastattelijana Marko Jouste. Ateena 27.12. 1993 Haastattelijana Marko Jouste. Ateena 3.1. 
Jouste

Äänitteet:

EMI 062-1702001

Markos Vamvakaris 1 1932-1965: A1 Alaniaris B7 Alana Pireotisa EFA-Trikont CD 00071

Fünf Grieschen in der Hölle und andre Rembetika-Lieder. Musik der städtichen Subkultur Griechenlands: A1 Garsona A8 Mes tis Pendelis ta vouna Margo 8180

Oi Megalo tou Rebetika 3. A3 Fandazes san prigipessa.

D.P.I. Atheneum EPE K.6.558

Rebetika Tragoudia no 13. Stratos Pajoumdzis. A3 Mes tis Pendelis ta vouna MBI CD 119

Pireotiko \& Amané. Authentic Rebetika Of U.S.A. Historic Urban Folk Songs From Greece. 17 Smyrneikos Manes 18 Hiotikos Manes 